\title{
Heavy Metals Contamination in Shellfish: Benefit-Risk Evaluation in Central Italy
}

\author{
Francesca Barchiesi ${ }^{1}$, Raffaella Branciari ${ }^{2, *}$ (D), Mario Latini ${ }^{1}$, Rossana Roila ${ }^{2}$, \\ Giuseppe Lediani ${ }^{3}$, Giovanni Filippini ${ }^{1}$, Giampiero Scortichini ${ }^{1}$, Arianna Piersanti ${ }^{1}$, \\ Elena Rocchegiani ${ }^{1}$ and David Ranucci ${ }^{2}$ \\ 1 Istituto Zooprofilattico Sperimentale dell’Umbria e delle Marche “Togo Rosati”, 06126 Perugia, Italy; \\ f.barchiesi@izsum.it (F.B.); m.latini@izsum.it (M.L.); g.filippini@izsum.it (G.F.); g.scortichini@izsum.it (G.S.); \\ a.piersanti@izsum.it (A.P.); e.rocchegiani@izsum.it (E.R.) \\ 2 Department of Veterinary Medicine, University of Perugia, Via San Costanzo 4, 06121 Perugia, Italy; \\ rossana.roila@unipg.it (R.R.); david.ranucci@unipg.it (D.R.) \\ 3 Italian Ministry of Health DGSAN Ufficio 2, Viale Giorgio Ribotta, 5, 00144 Roma, Italy; g.lediani@sanita.it \\ * Correspondence: raffaella.branciari@unipg.it
}

Received: 21 October 2020; Accepted: 20 November 2020; Published: 23 November 2020

check for updates

\begin{abstract}
Seafood is a source of nutrients in human diet but also of environmental contaminants and its consumption could pose a risk to consumers' health. A survey regarding the exposure to cadmium, lead and mercury through the consumption of bivalve mollusks, gastropods and sea urchins collected on Italian coasts was carried out among central Italian population over a period of three years. A limited number of samples exceeds the threshold set by legislation (6 samples) and the average level of contamination was low in all the species considered. The contribution Acceptable Daily Intake (ADI) was higher for cadmium (9.17\%) than lead $(1.44 \%)$ and mercury $(0.20 \%)$. The benefit-risk evaluation suggests that the bivalve mollusks and sea urchins consumption (Benefit Risk Quotient $<1$ ) could be increased without health detrimental effects.
\end{abstract}

Keywords: cadmium; lead; mercury; shellfish; gastropods; sea urchins; dietary intake; dietary exposure

\section{Introduction}

Heavy metals are known for adverse toxicological effects in humans and food products are considered to be their main source of exposure for general population [1-4]. Chronic cadmium (Cd) intake is responsible for different organ systems toxicity with reproductive and fertility impairments, skeletal damage, urinary and cardiovascular disorders, central and peripheral nervous deficiency, kidney disease and cancer [5-7]. Mercury (Hg) toxicity in nervous, motor, renal, cardiovascular, reproductive, and immune system is reported even at low dose [4,8]. Lead $(\mathrm{Pb})$ is responsible for negative effects on hematopoietic, renal, cardiovascular, reproductive and skeletal systems $[3,9,10]$.

Fish and seafood are regarded as one of the main food sources of these three contaminants as they live in marine environment that could be contaminated by these ubiquitous molecules, which are prone to high distribution in spite of their anthropic or natural origin [11], and they can accumulate $\mathrm{Cd}, \mathrm{Hg}$ and $\mathrm{Pb}$ in their tissue even to a high level [12-14].

Maximum limits in various fish and shellfish species are set for these contaminants in different countries [15-18] and, therefore, monitoring their levels in seafood is of utmost importance [11]. Nonetheless, taking into account the consumers' habits, a risk based approach to heavy metals exposure has to be considered [2-4,19-21] for the different seafood available on the market, the ingested dose and the potential beneficial health effects of seafood consumption. Especially, shellfish are considered a valuable source of unsaturated $\mathrm{n} 3$ fatty acids such as eicosapentaenoic acid (EPA) and 
docosahexaenoic acid (DHA) $[22,23]$. These compounds are proved to exert beneficial effects on human health $[24,25]$, and fish and shellfish consumption could represent a valuable strategy to enhance their dietary intake [26-28].

The production of bivalve mollusks is considered a sustainable practice as it has a low environmental impact due to limited exploitation of natural resources and to low maintenance costs [29]. Furthermore, Italy is characterized by a wide availability of coastlines which could be more extensively destined to seafood production. Moreover, although the consumption of this products in Italy is already noticeable (17.7\% of the economic value of all the fish products consumed in 2018) [30], it could be potentially increased in order to favor the dietary intake of valuable nutrients [31]. In this context a risk-benefit evaluation related to the consumption of seafood, can be considered of utmost importance for the fish sector as well as for consumers public health [32].

The aims of this work were the definition of $\mathrm{Cd}, \mathrm{Hg}$ ad $\mathrm{Pb}$ contamination level in marine shellfish, gastropods and sea urchins harvested along the Italian coastline; the assessment of central Italy population exposure; and the benefit-risk evaluation associated to the consumption of these selected products.

\section{Materials and Methods}

\subsection{Data Source}

The analytical results for $\mathrm{Cd}, \mathrm{Hg}$ and $\mathrm{Pb}$ in shellfish $(\mathrm{N}=2207$ after data cleaning) collected along the Italian coastline, from January 2017 until December 2019, were retrieved from SINVSA (Sistema informativo Nazionale Veterinario per la Sicurezza Alimentare), the Platform for Food Safety of the Department for Veterinary Public Health, Nutrition and Food Safety of the Ministry of Health.

SINVSA is a web application, created by the CSN (Centro Servizi Nazionale-Istituto Zooprofilattico Sperimentale dell'Abruzzo e del Molise) and it has been designed to collect information useful for risk assessment in feed and food along the whole production chain, making available all the information related to the industries registry, the official control and the analytical results. It includes all the data on national companies producing food for human consumption and animal feed including the transport and sub-products sector.

The seafood species considered in the survey were bivalve mollusks, gastropods and echinoderms (grouped in classes as reported in Table 1) collected from the coasts of 12 Italian regions (Figure 1).

Data management and descriptive statistical analyses were carried out using Excel datasheet (Microsoft) and Stata $11^{\circledR}$.

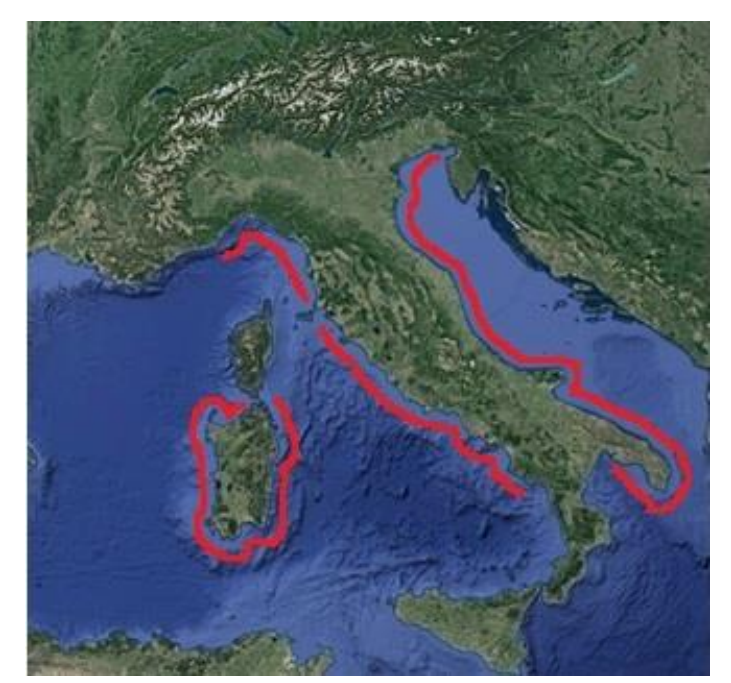

Figure 1. Italian coastline considered for the sampling collection. 
Table 1. Seafood classes and species considered.

\begin{tabular}{lc}
\hline \multicolumn{1}{c}{ Classes } & Species Scientific Name \\
\hline Bivalve mollusks & Mytilus galloprovincialis \\
Mussel & Mytilus edulis \\
& Modiolus barbatus \\
Clam & Ruditapes decussatus \\
& Ruditapes phylippinarum \\
& Chamelea gallina \\
Oyster & Venus verrucosa \\
& Ostrea edulis \\
Scallop & Crassostrea gigas \\
& Crassostrea angulata \\
& Flexopecten glaber \\
Brown venus & Pecten spp. \\
Razor clam & Mimachlamys varia \\
Other bivalves & Chlamys spp. \\
& Callista chione \\
& Solen siliqua \\
Echinoderms & Arca noae \\
Sea urchins & Cardium edule \\
Marine Gastropods & Cerastoderma spp. \\
Gastropods & Donax trunculus \\
& Hexaplex trunculus \\
& Nassarius mutabilis \\
& Muricidae \\
& Buccinus brandaris \\
& \\
& \\
& Paracentrotus lividus \\
&
\end{tabular}

\subsection{Data Collections}

The shellfish analyzed to assess heavy metals contamination were collected by local official competent authority in charge of bivalve mollusks production areas, during classification and monitoring activities compliant to EU regulation [33,34]. $\mathrm{Pb}, \mathrm{Cd}$ and $\mathrm{Hg}$, were analyzed by official laboratories following UNI CEI EN ISO/IEC 17025 accredited analytical methods [35] and Regulation $333 / 2007 / \mathrm{EC}$ [36] as far as sampling protocols and analytical performances are concerned.

$\mathrm{Pb}, \mathrm{Cd}, \mathrm{Hg}$ were analyzed in $1 \mathrm{~g}$ of sample after microwave digestion with $6 \mathrm{~mL} \mathrm{HNO}_{3}(67-69 \%$, $v / v), 2 \mathrm{~mL} \mathrm{H}_{2} \mathrm{O}_{2}(30 \%, v / v)$, and $100 \mathrm{~mL} \mathrm{HF}(40 \%, v / v)$.

The appropriately diluted solutions were analyzed by inductively coupled plasma mass spectrometry (ICP-MS) in standard mode using specific mass-to-charge ratios $(\mathrm{m} / \mathrm{z})$ for each element $(206+207+208 \mathrm{~Pb}, 111 \mathrm{Cd}, 202 \mathrm{Hg}$ ). Internal standards (i.e., 103Rh) were used to normalize the instrumental response and quantification was matrix-matched. The analytical methods were fully validated in intra-laboratory reproducibility conditions. The LOQs $(\mathrm{mg} / \mathrm{kg})$ of the method were: $\mathrm{Pb}=0.015, \mathrm{Cd}=0.005, \mathrm{Hg}=0.025$. Batch-to-batch precision and accuracy were evaluated by analyzing certified reference materials (Mussel Tissue SRM 2976, NIST Canada).

\subsection{Dietary Exposure and Risk Characterization}

For the definition of contaminants concentration in foodstuff, the left censored data was handled through substitution method. Therefore, when an element concentration was not quantified $(<\mathrm{LOQ})$ its value was assumed to be half of its LOQ according to the middle bound (MB) approach [24,37].

The population exposure to $\mathrm{Cd}, \mathrm{Hg}$ and $\mathrm{Pb}$ was assessed by combining seafood classes and contamination results $(\mathrm{MB})$ with specific consumption data, obtained through a detailed questionnaire. 
Seafood consumption data was derived from a questionnaire administered to 611 residents in central Italy, on both coastal and inland (almost $50 \mathrm{~km}$ far from the coast) sites. The participants were 357 females and 253 males; 310 records were obtained from consumers living along the coasts and 301 in the inland. The age of targeted population ranged from 18 to 75 years. The questionnaire was designed to obtain information on the bivalves and echinoderms consumption frequency and consumer's answers were combined with the food portion size data reported by Italian dietary surveys [38]. The questionnaires were returned anonymously, the participants did not receive any incentives and their consent had been obtained prior to the survey.

The dietary exposure assessment was conducted as reported by Branciari et al. [39] taking into consideration an average adult weighing $70 \mathrm{~kg}$, all the seafood products and the three target heavy metals.

In order to perform a risk characterization, the results of the exposure assessment were compared to the reference health-based guidance values set for cadmium ( $\mathrm{Cd}=0.35 \mathrm{ug} / \mathrm{kg}$ bw/d) [40], lead $(\mathrm{Pb}=0.004 \mathrm{mg} / \mathrm{kg} \mathrm{bw} / \mathrm{d})[41]$ and mercury $(\mathrm{Hg}=0.571 \mathrm{ug} / \mathrm{kg}$ bw/d) [42]. This approach allows to carry out a quantitative evaluation of the potentially harmful effects on consumers' health in relevance to the ingestion of these metals. The results of the risk characterization were expressed as percentage contribution to the Acceptable/Tolerable Daily Intake (ADI/TDI), which represents the amount of a substance in food that can be ingested on a daily basis over a lifetime without a significant health risk [43].

\subsection{EPA and DHA in Seafood and Benefits-Risks Assessment}

Aiming to quantitatively estimate the health benefits of seafood consumption, the EPA and DHA content in mollusks and echinoderms considered, was obtained from literature [32-44] (Figure 2). The daily dietary intake of such nutrients in the target population was assessed with the same methodology adopted for contaminants.

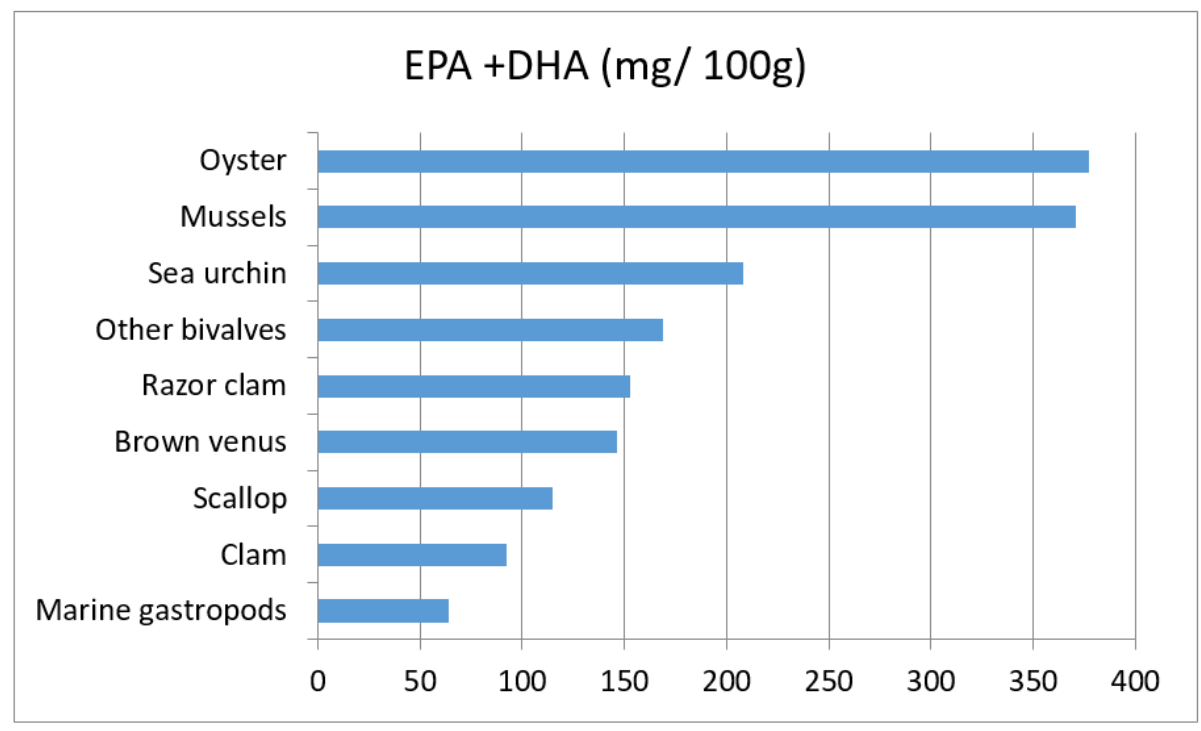

Figure 2. EPA and DHA content in the selected seafood.

Furthermore, to esteem the risks and benefits related to the consumption of the targeted seafood classes, the benefits-risks quotient (BRQ) approach was applied [20]. The benefit of seafood consumption refers principally to the intake of EPA and DHA, recognized as protective factors in cardiovascular diseases and defined as the contribution of the exposure values to the recommended Dietary Reference Intake (RDI) of $250 \mathrm{mg} / \mathrm{d}$ for EPA + DHA [24]. Therefore, the contents of the mentioned polyunsaturated fatty acids (PUFA) in the seafood classes considered (Figure 2), were combined with the consumption 
data. Risk factors were attributed to the ingestion of the targeted metals $(\mathrm{Cd}, \mathrm{Pb}, \mathrm{Hg})$ which have been proved to be toxic to humans.

The data was obtained from Prato et al. [32] for oyster, scallop, mussels, brown venus, razor clam, clam and other bivalves, and from Rincón-Cervera et al. [44] for sea urchins and marine gastropods.

$B R Q$ values estimate the benfit-risk of the simultaneous ingestion of PUFA and contaminants through seafood species and were calculated according to the following equation [20]:

$$
B R Q=\frac{Q_{F A}}{Q_{T}}
$$

$Q_{F A}$ is defined as follows:

$$
Q_{F A}=\frac{R_{F A}}{C_{F A}}
$$

where $R_{F A}(\mathrm{mg} / \mathrm{d}$ ) is the recommended daily intake of EPA + DHA (RDI of $250 \mathrm{mg} / \mathrm{d}$ for a healthy adult [24] was applied), while $C_{F A}(\mathrm{mg} / \mathrm{g})$ represents the concentration of EPA + DHA in seafood.

The maximum allowable food consumption related to toxic effects $\left(Q_{\mathrm{T}}\right)$ can be calculated according to the following equation:

$$
Q_{T}=\frac{R f D * B W}{c}
$$

where $R f D(\mathrm{mg} / \mathrm{kg}$ bw/d) is the reference dose of a pollutant defined through the ADI/TDI of each contaminant considered, $B W$ is the standard bodyweight set, as mentioned above, at $70 \mathrm{~kg}$, and $c$ $(\mathrm{mg} / \mathrm{g})$ is the concentration of each toxic molecule in the targeted food products.

$B R Q$ values below 1 suggest that achieving the recommended intake of EPA + DHA poses no evident risk to human health related to the simultaneous intake of the pollutant through seafood consumption $[19,20]$.

\section{Results and Discussion}

The results of $\mathrm{Cd}, \mathrm{Hg}$ and $\mathrm{Pb}$ in shellfish, gastropods and echinoderms for the three-year survey are presented in Tables $2-4$. For $\mathrm{Pb}$ the concentration was always under the maximum limits set by EU Regulation (MRL= $1.5 \mathrm{mg} / \mathrm{kg}$ ) [16], for Hg 1 sample (1 sea urchin in 2017) exceeds the maximum (MRL $=0.50 \mathrm{mg} / \mathrm{kg}$ ) and for Cd 5 samples (1 mussel in 2017 and 4 gastropods in 2018) exceed maximum level (MRL $=1.0 \mathrm{mg} / \mathrm{kg}$ ). Scallops and brown venus samples were always above LOQ for $\mathrm{Cd}$, nonetheless, the other classes have only few samples below LOQ. Cadmium levels were higher in oysters (average middle bound $\mathrm{MB}=0.218 \mathrm{mg} / \mathrm{kg}$ ) and gastropods $(\mathrm{MB}=0.217 \mathrm{mg} / \mathrm{kg}$ ) followed by scallops ( $\mathrm{MB}=0.117 \mathrm{mg} / \mathrm{kg}$ ). These results may be explained in respect to the different filtering capacity of the species, the specific living environment and, therefore, their accumulation abilities $[45,46]$. The values recorded in the present survey are similar to those referred for shellfish by other authors $[43,47,48]$, even though other shellfish species, collected in different environmental conditions, showed higher levels on specific sites [49]. However, higher Cd values are registered in gastropods and oyster [44,48]. A relevant factor influencing the bivalves capacity in accumulating $\mathrm{Cd}$, particularly oysters, is their position in the water column. Indeed oysters, growing at the bottom, can accumulate $\mathrm{Cd}$ up to 10 times higher than oysters growing in the same site, in baskets placed in the surface of the water [45]. As reported in literature, Cd concentration tends to be higher in deeper waters and decreases in surface water [50]. Concerning gastropods, the possible factors implicated in $\mathrm{Cd}$ accumulation could be their living environment (they generally live buried in fine sediments [51]) and the presence of Cd-binding proteins (metallothioneins) in their body, which are involved in shell formation $[52,53]$. 
Table 2. Cadmium (Cd) levels ( $\mathrm{mg} / \mathrm{kg}$ ) in selected seafood in the three-year period.

\begin{tabular}{|c|c|c|c|c|c|c|}
\hline Year & Classes & $\begin{array}{l}\text { Analyzed } \\
\text { Samples }\end{array}$ & $\begin{array}{l}\text { Above LOQ } \\
\text { Samples (\%) }\end{array}$ & Min & Max & Average (MB) ${ }^{1}$ \\
\hline \multirow[t]{9}{*}{2017} & Mussel & 152 & $137 /(90)$ & 0.030 & 1.150 & 0.099 \\
\hline & Clam & 260 & $226 /(87)$ & 0.010 & 0.140 & 0.035 \\
\hline & Oyster & 7 & $7 /(100)$ & 0.130 & 0.530 & 0.240 \\
\hline & Scallop & 37 & $37 /(100)$ & 0.050 & 0.370 & 0.100 \\
\hline & Brown venus & 36 & $36 /(100)$ & 0.010 & 0.060 & 0.030 \\
\hline & Razor clam & 1 & $1 /(100)$ & 0.003 & & 0.003 \\
\hline & Other bivalves & 28 & $9 /(32)$ & 0.010 & 0.270 & 0.024 \\
\hline & Gastropods & 59 & $56 /(95)$ & 0.010 & 0.770 & 0.228 \\
\hline & Echinoderms & 1 & $0 /(0)$ & & & 0.003 \\
\hline \multirow[t]{9}{*}{2018} & Mussel & 301 & $287 /(95)$ & 0.010 & 0.880 & 0.105 \\
\hline & Clam & 308 & $267 /(87)$ & 0.010 & 0.170 & 0.044 \\
\hline & Oyster & 47 & $46 /(98)$ & 0.070 & 0.840 & 0.235 \\
\hline & Scallop & 38 & $38 /(100)$ & 0.050 & 0.400 & 0.110 \\
\hline & Brown venus & 36 & $36 /(100)$ & 0.010 & 0.080 & 0.040 \\
\hline & Razor clam & 16 & $16 /(100)$ & 0.010 & 0.060 & 0.020 \\
\hline & Other bivalves & 30 & $6 /(20)$ & 0.010 & 0.350 & 0.028 \\
\hline & Gastropods & 44 & $43 /(98)$ & 0.010 & 1.880 & 0.303 \\
\hline & Echinoderms & 9 & $9 /(100)$ & 0.020 & 0.300 & 0.060 \\
\hline \multirow[t]{9}{*}{2019} & Mussel & 265 & $239 /(90)$ & 0.020 & 1.000 & 0.108 \\
\hline & Clam & 276 & $232 /(84)$ & 0.010 & 0.180 & 0.034 \\
\hline & Oyster & 40 & 38/(95) & 0.060 & 0.880 & 0.181 \\
\hline & Scallop & 25 & $25 /(100)$ & 0.060 & 0.400 & 0.140 \\
\hline & Brown venus & 26 & $26 /(100)$ & 0.020 & 0.070 & 0.030 \\
\hline & Razor clam & 25 & $20 /(80)$ & 0.010 & 0.340 & 0.033 \\
\hline & Other bivalves & 24 & $2 /(8)$ & 0.010 & 0.280 & 0.014 \\
\hline & Gastropods & 17 & $17 /(100)$ & 0.010 & 0.470 & 0.120 \\
\hline & Echinoderms & 8 & $8 /(100)$ & 0.020 & 0.080 & 0.050 \\
\hline
\end{tabular}

${ }^{1} \mathrm{MB}=$ middle bound.

Regarding $\mathrm{Hg}$, the number of samples above LOQ was lower than those recorded for $\mathrm{Cd}$ and $\mathrm{Pb}$; the number of above LOQ samples for $\mathrm{Hg}$ recorded in gastropods and brown venus was higher than in the other species analyzed. Samples of razor clam revealed the highest level of $\mathrm{Hg}$ contamination (an average of $\mathrm{MB}=0.087 \mathrm{mg} / \mathrm{kg}$ ), followed by gastropods and mussels (an average of $\mathrm{MB}=0.036$ and $0.024 \mathrm{mg} / \mathrm{kg}$, respectively).

The data is compliant to that reported in literature and show a relatively low $\mathrm{Hg}$ contamination in shellfish $[32,45,49,54]$. It is well known that $\mathrm{Hg}$, as a result of its bioaccumulation and biomagnification capacity in marine environment, tends to reach higher levels in predator fish which are the most relevant food exposure source to humans [4,54-56].

The selected seafood always shows a prevalence of samples above LOQ close to $100 \%$ for $\mathrm{Pb}$. The highest average bivalve mollusks values were detected in sea urchins $(0.203 \mathrm{mg} / \mathrm{kg})$ followed by scallops $(0.191 \mathrm{mg} / \mathrm{kg})$ and mussels $(0.174 \mathrm{mg} / \mathrm{kg})$. Similar results are reported for different shellfish harvested in the north Adriatic Sea [32,45] and in the South of Spain [47], but they are higher than on some specific sites on the East African coast (i.e., the Gulf of Suez) [50]. Even echinoderm can accumulate $\mathrm{Pb}$ and other heavy metals present in the marine environment [57]. Among echinoderms, the purple sea urchin is considered a bio-indicator for the monitoring of metal pollution along the Mediterranean and Atlantic coasts $[58,59]$ as it is able to concentrate the pollutants to a greater extent than all the other shellfish. Consequently, sea urchins remarkably contribute to transfer heavy metals and other pollutants to higher trophic levels [60]. 
Table 3. Mercury $(\mathrm{Hg})$ levels $(\mathrm{mg} / \mathrm{kg})$ in selected seafood over the three-year period.

\begin{tabular}{|c|c|c|c|c|c|c|}
\hline Year & Classes & $\begin{array}{l}\text { Analyzed } \\
\text { Samples }\end{array}$ & $\begin{array}{l}\text { Above LOQ } \\
\text { Samples (\%) }\end{array}$ & Min & $\operatorname{Max}$ & Average(MB) ${ }^{1}$ \\
\hline \multirow[t]{9}{*}{2017} & Mussel & 185 & $71 /(38)$ & 0.030 & 0.300 & 0.038 \\
\hline & Clam & 260 & $64 /(25)$ & 0.030 & 0.140 & 0.024 \\
\hline & Oyster & 7 & $2 /(29)$ & 0.030 & 0.110 & 0.029 \\
\hline & Scallop & 37 & $0 /(0)$ & & & 0.013 \\
\hline & Brown venus & 36 & $13 /(36)$ & 0.030 & 0.070 & 0.022 \\
\hline & Razor clam & 1 & $0 /(0)$ & & & 0.010 \\
\hline & Other bivalves & 28 & $9 /(32)$ & 0.030 & 0.170 & 0.028 \\
\hline & Gastropods & 59 & $51 /(86)$ & 0.030 & 0.100 & 0.045 \\
\hline & Echinoderms & 55 & $1 /(20)$ & 0.063 & & 0.024 \\
\hline \multirow[t]{9}{*}{2018} & Mussel & 302 & $104 /(34)$ & 0.030 & 0.190 & 0.032 \\
\hline & Clam & 308 & $89 /(29)$ & 0.030 & 0.180 & 0.023 \\
\hline & Oyster & 47 & $17 /(36)$ & 0.030 & 0.260 & 0.026 \\
\hline & Scallop & 38 & $0 /(0)$ & & & 0.013 \\
\hline & Brown venus & 36 & $27 /(75)$ & 0.030 & 0.090 & 0.041 \\
\hline & Razor clam & 16 & $13 /(81)$ & 0.070 & 0.210 & 0.108 \\
\hline & Other bivalves & 29 & $1 /(3)$ & 0.040 & & 0.013 \\
\hline & Gastropods & 44 & $34 /(77)$ & 0.030 & 0.100 & 0.034 \\
\hline & Echinoderms & 10 & $1 /(10)$ & 0.040 & & 0.015 \\
\hline \multirow[t]{9}{*}{2019} & Mussel & 265 & $34 /(13)$ & 0.030 & 0.170 & 0.017 \\
\hline & Clam & 276 & $70 /(25)$ & 0.030 & 0.130 & 0.022 \\
\hline & Oyster & 40 & $7 /(18)$ & 0.030 & 0.110 & 0.019 \\
\hline & Scallop & 25 & $0 /(0)$ & & & 0.013 \\
\hline & Brown venus & 26 & 19/(73) & 0.030 & 0.060 & 0.033 \\
\hline & Razor clam & 25 & $14 /(56)$ & 0.700 & 0.230 & 0.084 \\
\hline & Other bivalves & 24 & $1 /(4)$ & 0.040 & & 0.014 \\
\hline & Gastropods & 17 & $8 /(47)$ & 0.030 & 0.100 & 0.030 \\
\hline & Echinoderms & 10 & $2 /(20)$ & 0.030 & 0.040 & 0.018 \\
\hline
\end{tabular}

Table 4. Lead $(\mathrm{Pb})$ levels $(\mathrm{mg} / \mathrm{kg})$ in selected seafood over the three-year period.

\begin{tabular}{ccccccc}
\hline Year & Classes & $\begin{array}{c}\text { Analyzed } \\
\text { Samples }\end{array}$ & $\begin{array}{c}\text { Above LOQ } \\
\text { Samples (\%) }\end{array}$ & Min & Max & Average(MB) ${ }^{\mathbf{1}}$ \\
\hline \multirow{2}{*}{2017} & Mussel & 152 & $138 /(91)$ & 0.040 & 0.560 & 0.128 \\
& Clam & 260 & $223 /(86)$ & 0.020 & 0.350 & 0.078 \\
& Oyster & 7 & $7 /(100)$ & 0.090 & 0.400 & 0.190 \\
& Scallop & 37 & $37 /(100)$ & 0.020 & 0.500 & 0.150 \\
& Brown venus & 36 & $36 /(100)$ & 0.030 & 0.260 & 0.110 \\
Razor clam & 1 & 0 & & & 0.008 \\
& Other bivalves & 28 & $25 /(89)$ & 0.030 & 0.450 & 0.117 \\
Gastropods & 59 & $44 /(75)$ & 0.020 & 0.170 & 0.032 \\
& Echinoderms & 4 & $4 /(100)$ & 0.050 & 0.370 & 0.190 \\
\hline Mussel & 302 & $285 /(94)$ & 0.020 & 0.740 & 0.180 \\
& Clam & 308 & $267 /(87)$ & 0.020 & 0.740 & 0.114 \\
& Oyster & 47 & $47 /(100)$ & 0.030 & 0.780 & 0.150 \\
& Scallop & 38 & $37 /(97)$ & 0.030 & 0.420 & 0.175 \\
& Brown venus & 36 & $36 /(100)$ & 0.050 & 0.360 & 0.150 \\
Razor clam & 16 & $16 /(100)$ & 0.040 & 0.180 & 0.100 \\
& Other bivalves & 29 & $27 /(93)$ & 0.030 & 0.260 & 0.103 \\
Gastropods & 44 & $37 /(84)$ & 0.020 & 0.410 & 0.052 \\
Echinoderms & 10 & $10 /(100)$ & 0.040 & 0.400 & 0.200 \\
\hline
\end{tabular}


Table 4. Cont.

\begin{tabular}{ccccccc}
\hline Year & Classes & $\begin{array}{c}\text { Analyzed } \\
\text { Samples }\end{array}$ & $\begin{array}{c}\text { Above LOQ } \\
\text { Samples (\%) }\end{array}$ & Min & Max & Average(MB) ${ }^{\mathbf{1}}$ \\
\hline 2019 & Mussel & 265 & $236 /(89)$ & 0.020 & 1.070 & 0.215 \\
& Clam & 276 & $232 /(84)$ & 0.020 & 1.080 & 0.136 \\
& Oyster & 40 & $38 /(95)$ & 0.030 & 0.370 & 0.124 \\
& Scallop & 18 & $16 /(89)$ & 0.020 & 0.660 & 0.250 \\
& Brown venus & 26 & $26 /(100)$ & 0.070 & 0.430 & 0.230 \\
Razor clam & 25 & $24 /(96)$ & 0.070 & 0.590 & 0.212 \\
& Other bivalves & 24 & $24 /(100)$ & 0.040 & 0.530 & 0.130 \\
Gastropods & 17 & $16 /(94)$ & 0.020 & 0.310 & 0.104 \\
& Echinoderms & 10 & $10 /(100)$ & 0.020 & 0.520 & 0.220 \\
\hline
\end{tabular}

${ }^{1} \mathrm{MB}=$ middle bound.

As far as the risk characterization is concerned, the contribution to ADI of the various shellfish studied is reported in Figure 3. The average contribution of each product to ADI of the population considered was extremely low for $\mathrm{Hg}$ and $\mathrm{Pb}$, with values always below $1 \%$, but higher for $\mathrm{Cd}$, with values not exceeding $4 \%$. The contribution to ADI for the three metals was higher for mussels followed by clams, oysters and scallops. Regarding Cd, a contribution to ADI of $2 \%$ was recorded in gastropods: this value is relatively low, but it is higher than for shellfish and echinoderms. The consumption frequency and the portion size surely affect these results: mussels are the most frequently eaten shellfish included in the present survey (average consumption of $8.88 \mathrm{~g} / \mathrm{kg} \mathrm{bw} / \mathrm{die}$ for mussels and $9.12 \mathrm{~g} / \mathrm{kg}$ bw/die for clams, respect to $1.09 \mathrm{~g} / \mathrm{kg} \mathrm{bw} /$ die for oysters, $1.44 \mathrm{~g} / \mathrm{kg} \mathrm{bw} / \mathrm{die}$ for scallops, $1.27 \mathrm{~g} / \mathrm{kg}$ bw/die for brown venus, $1.44 \mathrm{~g} / \mathrm{kg}$ bw/die for razor clams and other bivalves $2.56 \mathrm{mg} / \mathrm{kg} \mathrm{bw} / \mathrm{die})$.

The contribution to ADI by sea urchins is limited as a result of a very low consumption $(1.25 \mathrm{~g} / \mathrm{kg}$ bw/die). On the other hand, gastropods, although modestly consumed ( $1.82 \mathrm{~g} / \mathrm{kg}$ bw/die), contribute to $\mathrm{Cd}$ ADI to a higher extent than other species considered, due to their accumulation capacity. The contribution of each species to ADI provides a measure of safety during long-term exposure upon consumption [43], therefore, the reported results (Figure 3) suggest a negligible public health risk of exposure to metals through the consumption of the seafood species taken into consideration. These results are in accordance with other authors [57] who state that there is no significant health risk of humans' exposure to $\mathrm{Cd}, \mathrm{Hg}$ and $\mathrm{Pb}$ upon consumption of shellfish. Furthermore, the bio accessibility for metals like cadmium in cooked shellfish is reduced and thus further mitigates health risk [61].

The overall mean contribution to the ADI of the three targeted metals upon the above seafood species consumption, dividing the population in respect to their geographical distribution (inland or coastal), is reported in Figure 4.

The results confirm a higher contribution to the reference value (ADI) in case of $\mathrm{Cd}$ in comparison to that of $\mathrm{Pb}$ and $\mathrm{Hg}$. The $\mathrm{Cd}$ contribution to $\mathrm{ADI}$ registered in coastal consumers was greater, probably due to a higher seafood consumption. This uneven contribution was not observed in the other heavy metals subject of the present study (Figure 4).

In this research, the benefit-risk quotient was applied in order to evaluate the simultaneous effect on human health of EPA and DHA ingestion and metal contaminants present in seafood products. As shown in Table 5, the $B R Q$ for most of the groups of seafood analyzed was $<1$, ranging between 0.00 and 0.57 . This result implies that healthy consumers potentially eating enough sea products to achieve the RDI for EPA + DHA, would not be exposed to an increased health risk due to the simultaneous exposure to the toxic metals analyzed. 


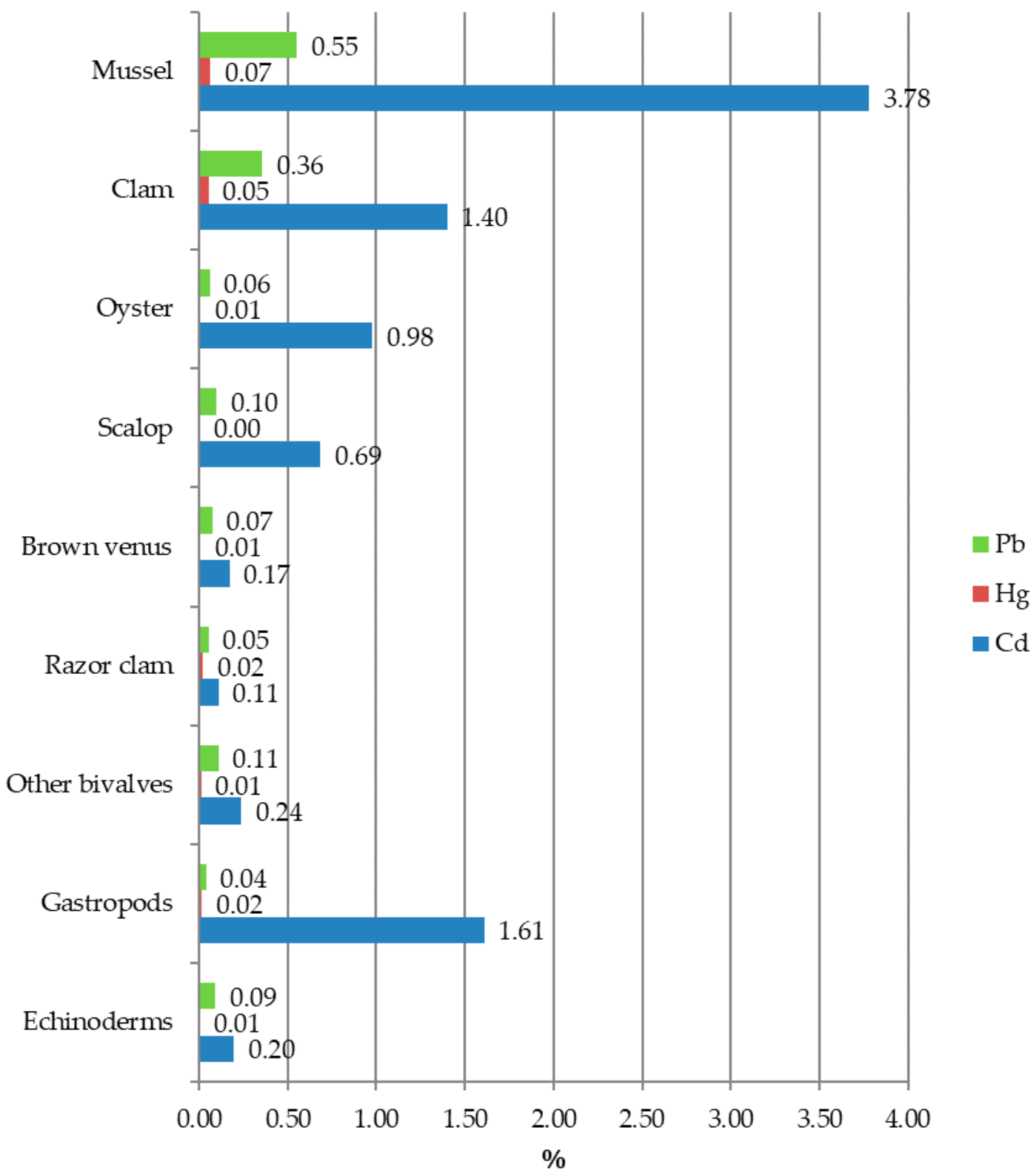

Figure 3. Contribution to the metals ADIs (\%) of the selected seafood.

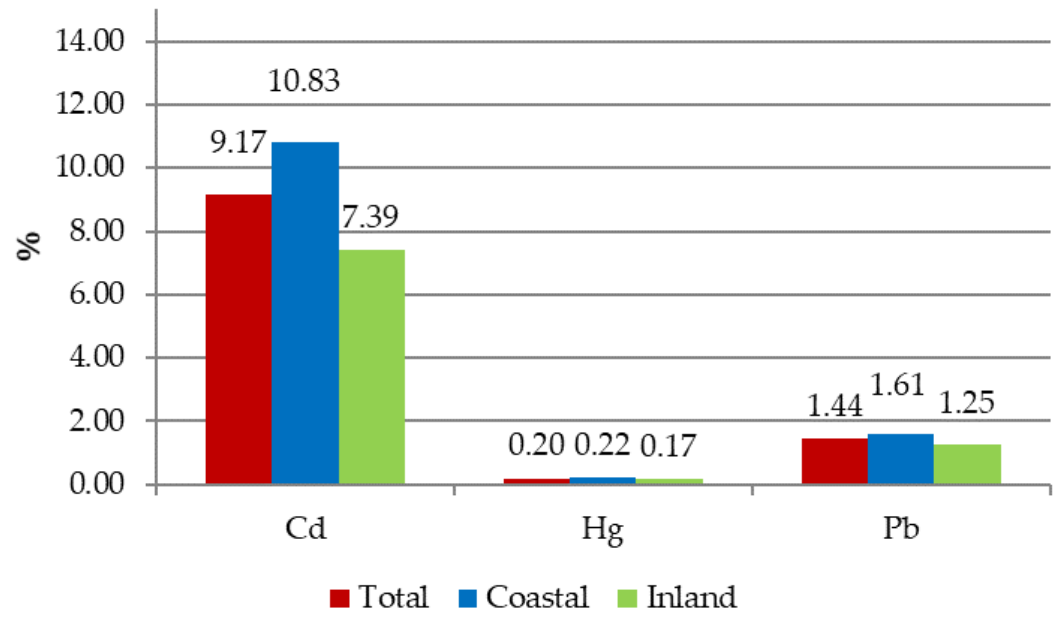

Figure 4. ADI contribution (\%) in relation to geographical distribution of population. 
Table 5. BRQ for $\mathrm{Cd}, \mathrm{Hg}$ and $\mathrm{Pb}$ in the selected seafood.

\begin{tabular}{lccc}
\hline & $\mathbf{C d}$ & $\mathbf{H g}$ & $\mathbf{P b}$ \\
\hline Mussel & 0.33 & 0.01 & 0.05 \\
Clam & 0.31 & 0.01 & 0.08 \\
Oyster & 0.57 & 0.00 & 0.04 \\
Scallop & 0.33 & 0.00 & 0.05 \\
Brown venus & 0.23 & 0.01 & 0.10 \\
Razor clam & 0.13 & 0.03 & 0.07 \\
Other bivalves & 0.13 & 0.00 & 0.00 \\
Gastropods & 3.46 & 0.00 & 0.00 \\
Echinoderms & 0.12 & 0.00 & 0.06 \\
\hline
\end{tabular}

The unique exception to this pattern is gastropods, registering a BRQ of 3.46 for $\mathrm{Cd}$, meaning that for this seafood species the risk associated with the exposure to this metal prevails over the benefits of polyunsaturated fatty acids intake. In spite of the moderate consumption of gastropods registered by the questioned population, this outcome is likely due to the combination of the low content of EPA+DHA (Table 1) and the relatively high concentration of metals associated with these marine species, due to their major route of trace metal uptake tracking [62].

However, as reported by other authors in different environments, these results confirm that the benefits of sea products intake should outweigh the associated risks, when considering the average healthy population [57].

\section{Conclusions}

The average levels of $\mathrm{Cd}, \mathrm{Hg}$ and $\mathrm{Pb}$ detected in mollusks and sea urchins from the Italian coastline are low and, therefore, the exposure of the targeted adult population to these metals is moderate, even when higher shellfish portions are consumed, as it is the habit of the coastal population. Benefit-risk evaluation revealed that the frequency of the above seafood consumption could be enhanced with the aim to increase EPA + DHA intake, without adverse effects.

Author Contributions: Conceptualization, F.B., D.R.; methodology, R.B.; formal analysis, A.R., E.R., M.L.; investigation, A.R., E.R., M.L.; resources, G.F., G.S.; data curation, R.R.; writing一 - original draft preparation, F.B., R.B., D.R.; writing-review and editing, A.P., G.L.; supervision, F.B., D.R.; All authors have read and agreed to the published version of the manuscript.

Funding: This research received no external funding.

Conflicts of Interest: The authors declare no conflict of interest.

\section{References}

1. Gall, J.E.; Boyd, R.S.; Rajakaruna, N. Transfer of heavy metals through terrestrial food webs: A review. Environ. Monit. Assess. 2015, 187, 201. [PubMed]

2. European Food Safety Agency. Cadmium dietary exposure in the European population. EFSA J. 2012, 10, 2551.

3. European Food Safety Agency. Lead dietary exposure in the European population. EFSA J. 2012, 10, 2831.

4. European Food Safety Agency. Scientific opinion on the risk for public health related to the presence of mercury and methylmercury in food. EFSA J. 2012, 10, 2985.

5. Kumar, S.; Sharma, A. Cadmium toxicity: Effects on human reproduction and fertility. Rev. Environ. Health 2015, 34, 327-338.

6. Fatima, G.; Raza, A.M.; Hadi, N.; Nigam, N.; Mahdi, A.A. Cadmium in human diseases: It's more than just a mere metal. Ind. J. Clin. Biochem. 2019, 34, 371-378.

7. Genchi, G.; Sinicropi, M.S.; Lauria, G.; Carocci, A.; Catalano, A. The effects of cadmium toxicity. Int. J. Environ. Res. Pub. Health 2020, 17, 3782.

8. Zahir, F.; Rizwi, S.J.; Haq, S.K.; Khan, R.H. Low dose mercury toxicity and human health. Environ. Toxicol. Pharmacol. 2005, 20, 351-360. 
9. Flora, G.; Gupta, D.; Tiwari, A. Toxicity of lead: A review with recent updates. Interdiscip. Toxicol. 2012, 5, 47-58.

10. Ara, A.; Usmani, J.A. Lead toxicity: A review. Interdiscip. Toxicol. 2015, 8, 55-64.

11. Bosch, A.C.; O’Neill, B.; Sigge, G.O.; Kerwath, S.E.; Hoffman, L.C. Heavy metals in marine fish meat and consumer health: A review. J. Sci. Food Agric. 2016, 96, 32-48. [PubMed]

12. Rashed, M.N. Cadmium and lead levels in fish (Tilapia nilotica) tissues as biological indicator for lake water pollution. Environ. Monit. Assess. 2001, 68, 75-89. [PubMed]

13. Jezierska, B.; Witeska, M. The metal uptake and accumulation in fish living in polluted waters. In Soil and Water Pollution Monitoring, Protection and Remediation; Twardowska, I., Allen, H.A., Häggblom, M.M., Stafaniak, S., Eds.; Springer: Dordrecht, The Netherlands, 2016; pp. 107-114.

14. Castilhos, Z.C.; Rodrigues-Filho, S.; Rodrigues, A.P.C.; Villas-Bôas, R.C.; Siegel, S.; Veiga, M.M.; Beinhoff, C. Mercury contamination in fish from gold mining areas in Indonesia and human health risk assessment. Sci. Total Environ. 2006, 368, 320-325. [PubMed]

15. UN Food and Agriculture Organization (FAO). Heavy Metals Regulations; Legal Notice No 66/2003; Food and Agriculture Organization (FAO): Rome, Italy, 2003.

16. The Commission of the European Communities. Commission regulation (EC) No 1881/2006. Off. J. Eur. Union 2006, 364, 5-24.

17. The Commission of the European Communities. Commission regulation (EC) no 629/2008. Off. J. Eur. Union 2008, 173, 6-9.

18. South African Department of Health (DOH). Foodstuffs, cosmetics and disinfectants act, 1972 (Act no. 54 of 1972). Gov. Gaz. 2004, 500, 4-6.

19. Gladyshev, M.I.; Sushchik, N.N.; Anishchenko, O.V.; Makhutova, O.N.; Kalachova, G.S.; Gribovskaya, I.V. Benefit-risk ratio of food fish intake as the source of essential fatty acids vs. heavy metals: A case study of Siberian grayling from the Yenisei River. Food Chem. 2009, 115, 545-550.

20. Geng, J.J.; Li, H.; Liu, J.P.; Yang, Y.; Jin, Z.L.; Zhang, Y.N.; Zhang, M.L.; Chen, L.Q.; Du, Z.Y. Nutrients and contaminants in tissues of five fish species obtained from Shanghai markets: Risk-benefit evaluation from human health perspectives. Sci. Total Environ. 2015, 536, 933-945.

21. Vilavert, L.; Borrell, F.; Nadal, M.; Jacobs, S.; Minnens, F.; Verbeke, W.; Marquez, A.; Domingo, J.L. Health risk/benefit information for consumers of fish and shellfish: FishChoice, a new online tool. Food Chem. Toxicol. 2017, 104, 79-84.

22. Tan, K.; Ma, H.; Li, S.; Zheng, H. Bivalves as future source of sustainable natural omega-3 polyunsaturated fatty acids. Food Chem. 2020, 311, 125907.

23. Zhang, T.T.; Xu, J.; Wang, Y.M.; Xue, C.H. Health benefits of dietary marine DHA/EPA-enriched glycerophospholipids. Prog. Lipid Res. 2019, 75, 100997. [PubMed]

24. European Food Safety Authority. Scientific opinion on the tolerable upper intake level of Eicosapentaenoic Acid (EPA), Docosahexaenoic Acid (DHA) and Docosapentaenoic Acid (DPA). EFSA J. 2012, 10, 2815.

25. Swanson, D.; Block, R.; Mousa, S.A. Omega-3 fatty acids EPA and DHA: Health benefits throughout life. Adv. Nutr. 2012, 3, 1-7.

26. Lund, E.K. Health benefits of seafood; is it just the fatty acids? Food Chem. 2013, 140, 413-420. [PubMed]

27. Cardoso, C.; Afonso, C.; Bandarra, N.M. Seafood lipids and cardiovascular health. Nutrire 2016, 41, 7.

28. Branciari, R.; Ranucci, D.; Urbani, E.; Valiani, A.; Trabalza-Marinucci, M.; dal Bosco, A.; Franceschini, R. Freshwater fish burgers made from four different fish species as a valuable strategy appreciated by consumers for introducing EPA and DHA into a human diet. J. Aquat. Food Prod. Technol. 2017, 26, 686-694.

29. Froehlich, H.E.; Gentry, R.R.; Halpern, B.S. Global change in marine aquaculture production potential under climate change. Nat. Ecol. Evol. 2018, 2, 1745-1750.

30. Borsa Merci Telematica Italiana. Report Annual Sul Mercato Ittico-Anno 2018; Borsa Merci Telematica Italiana, Ed.; Borsa Merci Telematica Italiana: Roma, Italy, 2018.

31. Venugopal, V.; Gopakumar, K. Shellfish: Nutritive value, health benefits, and consumer safety. Compr. Rev. Food Sci. Food Saf. 2017, 16, 1219-1242.

32. Prato, E.; Biandolino, F.; Parlapiano, I.; Giandomenico, S.; Denti, G.; Calò, M.; Spada, L.; di Leo, A. Proximate, fatty acids and metals in edible marine bivalves from Italian market: Beneficial and risk for consumers health. Sci. Total Environ. 2019, 648, 153-163. 
33. The Commission of the European Communities. Commission regulation (EC) No 853/2004. Off. J. Eur. Union 2004, 139, 55-205.

34. The Commission of the European Communities. Commission regulation (EC) No 854/2004. Off. J. Eur. Union 2004, 139, 206-320.

35. International Standard Organization. General Requirements for the Competence of Testing and Calibration Laboratories; ISO/IEC 17025:2018; International Standard Organization: Geneva, Switzerland, 2018.

36. The Commission of the European Communities. Commission regulation (EC) No 333/2007. Off. J. Eur. Union 2007, 88, 29-38.

37. Branciari, R.; Franceschini, R.; Roila, R.; Valiani, A.; Pecorelli, I.; Piersanti, A.; Houet, N.; Framboas, M.; Ranucci, D. Nutritional value and contaminant risk assessment of some commercially important fishes and crawfish of Lake Trasimeno, Italy. Int. J. Environ. Res. Public Health 2020, 17, 2545.

38. Società Italiana di Nutrizione Umana (SINU). Livelli di Assunzione di Riferimento di Nutrienti ed Energia per la Popolazione Italiana IV Revisione (LARN); Società Italiana di Comunicazione Scientifica e Sanitaria (SICS): Milan, Italy, 2014.

39. Branciari, R.; Roila, R.; Ranucci, D.; Altissimi, M.S.; Mercuri, M.L.; Haouet, N.M. Estimation of acrylamide exposure in Italian schoolchildren consuming a canteen menu: Health concern in three age groups. Int. J. Food Sci. Nutr. 2020, 71, 122-131.

40. European Food Safety Authority. Panel on contaminants in the food chain (CONTAM). Statement on tolerable weekly intake for cadmium. EFSA J. 2011, 9, 1975.

41. Food and Agriculture Organization (FAO); World Health Organization (WHO). Joint FAO/WHO food standards programme, codex committee on food additives and contaminants. In Proceedings of the 33rd Session CODEX, Hague, The Netherlands, 12-16 March 2001; pp. 121-126.

42. European Food Safety Authority. Panel on Contaminants in the food chain (CONTAM). Scientific opinion on the risk for public health related to the presence of mercury and methylmercury in food. EFSA J. 2018, 10, 2985.

43. Benford, D.J. Risk assessment of chemical contaminants and residues in foods. In Persistent Organic Pollutants and Toxic Metals in Foods; Rose, M., Fernandez, A., Eds.; Woodhead Publishing: Cambridge, UK, 2013; pp. 173-187.

44. Rincón-Cervera, M.Á.; González-Barriga, V.; Romero, J.; Rojas, R.; López-Arana, S. Quantification and distribution of omega-3 fatty acids in South Pacific fish and shellfish species. Foods 2020, 9, 233.

45. Bille, L.; Binato, G.; Cappa, V.; Toson, M.; dalla Pozza, M.; Arcangeli, G.; Ricci, A.; Angeletti, R.; Piro, R. Lead, mercury and cadmium levels in edible marine molluscs and echinoderms from the Veneto region (north-western Adriatic Sea-Italy). Food Control 2015, 50, 362-370.

46. Claisse, D. Accumulation des métauxlourds et polluants organiques par les coquillages. In Coquillages et Santé Publique. Durisque à la Prévention; Lesne, J., Ed.; ENS: Rennes, France, 1992; pp. 99-111.

47. Olmedo, P.; Pla, A.; Hernández, A.F.; Barbier, F.; Ayouni, L.; Gil, F. Determination of toxic elements (mercury, cadmium, lead, tin and arsenic) in fish and shellfish samples. Risk assessment for the consumers. Environ. Int. 2013, 59, 63-72.

48. María-Cervantes, A.; Jiménez-Cárceles, F.J.; Álvarez-Rogel, J. As, Cd, Cu, Mn, Pb, and Zn contents in sediments and mollusks (Hexaplextrunculus and Tapes decussatus) from coastal zones of a Mediterranean lagoon (Mar Menor, SE Spain) affected by mining wastes. Water Air Soil Pollut. 2009, 200, 289-304.

49. Tamele, I.J.; Loureiro, P.V. Lead, mercury and cadmium in fish and shellfish from the Indian Ocean and Red Sea (African Countries): Public health challenges. J. Mar. Sci. 2020, 8, 344.

50. Storelli, M.M.; Marcotrigiano, G.O. Cadmium and total mercury in some cephalopods from the South Adriatic Sea (Italy). Food Add. Contam. 1999, 16, 261-265.

51. Primost, M.A.; Gil, M.N.; Bigatti, G. High bioaccumulation of cadmium and other metals in Patagonian edible gastropods. Mar. Biol. Res. 2017, 13, 774-781.

52. Bigatti, G.; de Vivar, M.D.; Cumplido, M.; Vilela, R.N.; Avaro, M.; Sastre, V.; Gil, M. Fatty acids and contaminants in edible marine gastropods from Patagonia. J. Mar. Biolog. Assoc. UK 2018, 98, 1355-1363.

53. Roméo, M.; Gharbi-Bouraoui, S.; Gnassia-Barelli, M.; Dellali, M.; Aïssa, P. Responses of Hexaplex (Murex) trunculus to selected pollutants. Sci. Total Environ. 2006, 359, 135-144.

54. Millour, S.; Noël, L.; Kadar, A.; Chekri, R.; Vastel, C.; Sirot, V.; Leblanc, J.-C.; Guérin, T. Pb, Hg, Cd, As, Sb and $\mathrm{Al}$ levels in foodstuffs from the 2nd French total diet study. Food Chem. 2011, 126, 1787-1799. 
55. European Food Safety Authority. Statement on the benefits of fish/seafood consumption compared to the risks of methylmercury in fish/seafood. EFSA J. 2015, 13, 3982.

56. Burger, J.; Gochfeld, M. Mercury in canned tuna: White versus light and temporal variation. Environ. Res. 2004, 96, 239-249.

57. Noël, L.; Testu, C.; Chafey, C.; Velge, P.; Guérin, T. Contamination levels for lead, cadmium and mercury in marine gastropods, echinoderms and tunicates. Food Control 2011, 22, 433-437.

58. Warnau, M.; Ledent, G.; Temara, A.; Bouquegneau, J.M.; Jangoux, M.; Dubois, P. Heavy metals in Posidoniaoceanica and Paracentrotuslividus from seagrass beds of the north-western Mediterranean. Sci. Total Environ. 1995, 171, 95-99.

59. Warnau, M.; Biondo, R.; Temara, A.; Bouquegneau, J.M.; Jangoux, M.; Dubois, P. Distribution of heavy metals in the echinoid Paracentrotuslividus from the Mediterranean Posidoniaoceanica ecosystem: Seasonal and geographical variations. J. Sea Res. 1998, 39, 267-280.

60. Muir, D.; Braune, B.; DeMarch, B.; Norstrom, R.; Wagemann, R.; Lockhart, L.; Hargrave, B.; Bright, D.; Addison, R.; Payne, J.; et al. Spatial and temporal trends and effects of contaminants in the Canadian Arctic marine ecosystem: A review. Sci. Total Environ. 1999, 230, 83-144. [PubMed]

61. Houlbrèque, F.; Hervé-Fernández, P.; Teyssié, J.L.; Oberhaënsli, F.; Boisson, F.; Jeffree, R. Cooking makes cadmium contained in Chilean mussels less bioaccessible to humans. Food Chem. 2011, 126, 917-921.

62. Moolman, L.J.H.J.; van Vuren, J.H.J.; Wepener, V. Comparative studies on the uptake and effects of cadmium and zinc on the cellular energy allocation of two freshwater gastropods. Ecotoxicol. Environ. Saf. 2007, 68, 443-450.

Publisher's Note: MDPI stays neutral with regard to jurisdictional claims in published maps and institutional affiliations. 